\title{
MODELING OF APPROPRIATE NORMS OF PHYSICAL READINESS OF PRE-CONSCRIPTION YOUTH FOR SERVICE IN THE ARMY
}

\author{
Tatiana Krutsevich ${ }^{\mathrm{ABCD}}$, Natalia Panhelova ${ }^{2 \mathrm{ABCD}}$, Sergii Trachuk ${ }^{1 \mathrm{ABCD}}$, \\ Victor Kuibida $^{2 \mathrm{ABCD}}$, Roman Pidleteychuk ${ }^{1 \mathrm{ABCD}}$, Boris Panhelov ${ }^{2 \mathrm{ABCD}}$ \\ ${ }^{1}$ National University of Ukraine on Physical Education and Sport \\ ${ }^{2}$ Hryhorii Skovoroda University in Pereiaslav \\ Authors' Contribution: A - Study design; B - Data collection; C - Statistical analysis; D - Manuscript Preparation; E - Funds Collection
}

Corresponding Author: Sergii Trachuk, E-mail: trachuk_sergey@i.ua

Accepted for Publication: October 16, 2021

Published: December 25, 2021

DOI: 10.17309/tmfv.2021.4.05

\begin{abstract}
Research purpose: is a substantiation and modeling of appropriate norms of physical readiness of youth for service in the army.

Materials and Methods. The expert group included 21 specialists (whose field of activity is physical education, special training, physical training in the security and defense forces). The following research methods were used to solve the problem posed in the work: theoretical analysis, comparison, systematization and generalization of materials of scientific, historical, methodical literature and guiding documents; expert evaluation (Delphi and analysis of Saati hierarchies); methods of mathematical statistics.

Results. It is determined that even simple statistical methods in combination with expert information when choosing promising solutions often give better results than accurate calculations with a focus on averages. A comprehensive approach using peer review (Delphi), a method of modern theory of hierarchical systems Saati allowed to determine the structure of the projected model of physical fitness of young people for military service. The structural interconnected components of the predicted model with the corresponding weighting factors are the level of formation and development of general and special physical qualities $\left(\rho_{1}=0.411\right)$, the level of formation and development of special physical qualities $\left(\rho_{2}=0.235\right)$, the level of acquisition of military applied motor skills $\left(\rho_{3}=0.216\right)$, the state of the cardiovascular system $\left(\rho_{4}=0.138\right)$.

Conclusions. The presented structural predictable model of integrated assessment of physical readiness of youth for service in the army allows to define limits of levels of components and to estimate their level of formation in points from 1 to 12, and also to correct the maintenance of means of physical training depending on such components which lag behind a proper norm.

Keywords: pre-conscription youth, predicted models, proper norms, physical fitness.
\end{abstract}

\section{Introduction}

The real threats to Ukraine's sovereignty and territorial integrity necessitated an increase in the level of readiness of young people to fulfill their patriotic duty and, accordingly, a high level of functional and psychophysical preparedness. In these conditions, the issue of finding an effective system of training pre-conscription youth for service in the Armed Forces of Ukraine became especially relevant (Krutsevich, \& Trachuk, 2017).

A high level of physical fitness of young people is relevant, the army needs healthy, well-developed and well-

(C) Krutsevich, T., Panhelova, N., Trachuk, S., Kuibida, V., Pidleteychuk, R., \& Panhelov, B., 2021. trained young men, but not every average young man meets the requirements of tomorrow's service (Krutsevych, Sainchuk, Pidleteichuk, 2018).

Physical training, according to experts, is the main means of combat training of servicemen, as well as a structural component that ensures the combat effectiveness of the armed forces as a whole (Military Committee, 2009; Borodin, 2009; Romanchuk, 2012; Bosenko, Sudets, 2017; Aandstad, Sandberg, Hageberg, Kolle, 2020). Physical training is a basic factor for the implementation of technical and mental readiness of troops, a means of adaptation to militaryprofessional activities (Romanchuk, 2013; Olkhovoy, 2012; Romanchuk, C., Anokhin, Oderov, Klymovyh, Pidleteichuk, Dobrovolskii, Tychyna, 2020). 
The management system in physical education is based primarily on the operation of models, and only then - on the transfer of "samples" of pedagogical actions in practice (Priymak, 2003; Loshitska, 2007; Priymak, Krutsevich, Pangelova, Trachuk, Kravchenko, Stepanenko \& Ruban, 2020).

Possibilities of creation, construction of models are caused by specific features of its application (Olkhovyi, 2012; Krutsevich, 2017; Krutsevich, Pangelova, Trachuk, 2019). When two phenomena that can be objectively measured are identified and the relationship between them is quantifiable, this provision opens up opportunities for cybernetic modeling of processes (Krutsevich, T. 2017).

The availability of models determines the opportunities for teachers to guide young people to achieve the appropriate level, and the military - the information that young people who meet the model requirements, are characterized by a higher level of physical condition and are able to perform certain duties in the future, accordingly to the appointment, and the military registration and enlistment office, in turn, would be able to plan and direct conscripts to the appropriate regime training zone (Loshitska, 2007).

The aim of of the research was to study and modeling of appropriate norms of physical readiness of youth for service in the army.

\section{Materials and method}

\section{Study participants}

The expert group included 21 specialists (heads of physical training and sports of military units; teachers, heads of departments of physical education of special physical training and sports of higher military educational institutions of Ukraine.

\section{Study organization}

Methods of study: theoretical analysis, comparison, systematization and generalization of materials of scientific, historical, methodical literature and guiding documents; expert assessment (Delphi and analysis of hierarchies Saati); methods of mathematical statistics.

\section{Procedure}

According to the Delphi expert survey procedure, which was based on practical issues of leadership, organization and physical training of young people, their readiness for military service. Experts were given the main questions directly at the time of the survey, were not allowed to exchange views on problem, which ensured the independence of opinion. The survey procedure took place in stages:

- experts were asked to answer a list of questions formulated in detail on the research problem;

- each participant answered the questions anonymously;

- the results of the expert survey using the principle of pairwise comparisons of the degree of superiority of one component over another determine the weights of the indicators of integrated readiness assessment;

- each expert received a copy of the general document, followed by a discussion of the problem to be solved to adjust the components of the system of physical training and physical readiness of young people for military service.

\section{Results}

As a result of processing of data of expert estimations and quantitative comparison of pair comparisons of a degree of advantage of one component over another components of the forecasted model of physical readiness of a conscription contingent of Ukrainians for service in army were defined.

To obtain an objective assessment of the effectiveness of the process of physical training of conscripts for military service, based on the results of our work, we proposed a structural of predicted the model of integrated assessment of physical readiness of youth for service in the security and defense forces of Ukraine (Fig. 1).

In the course of the expert survey 21 experts managed to confirm the expediency and urgency of achieving the appropriate level of physical fitness in the process of conducting forms of physical culture (physical education) in the conscript contingent, which will contribute to the functional readiness of the cardiovascular system, acquisition and formation of military motor skills.

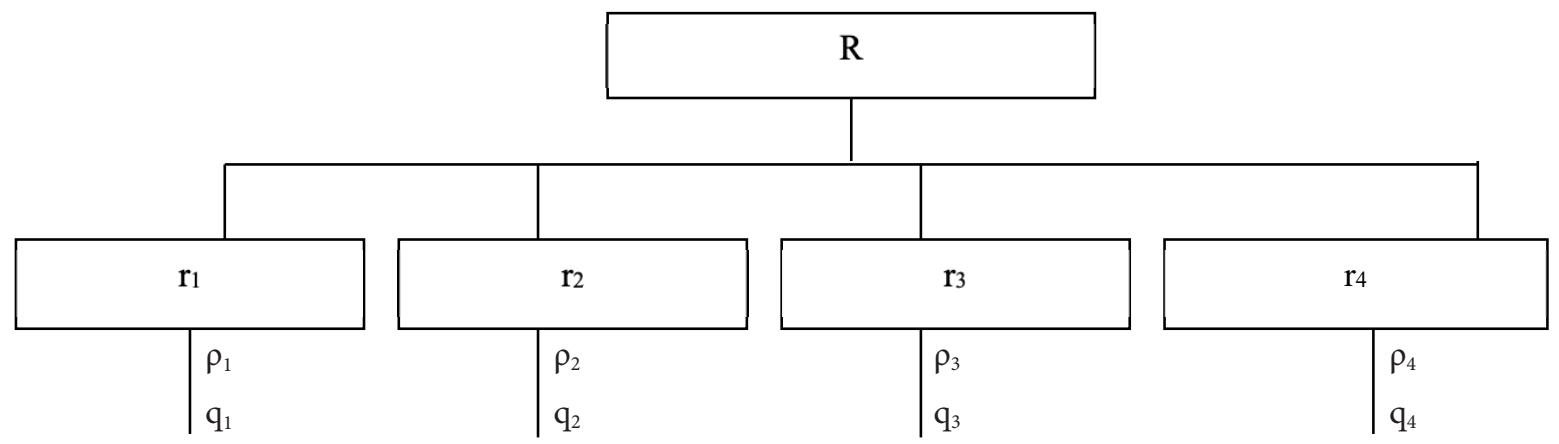

Fig. 1. Structural model of integrated assessment of physical readiness of young people for military service. Note: R - integrated assessment of young people's physical readiness for military service; $\mathrm{r}_{1}$ - the level of formation and development of general physical qualities; $r_{2}$ - the level of formation and development of special physical qualities; $r_{3}$ - level of acquisition of military-applied motor skills; $\mathrm{r}_{4}$ - the state of the cardiovascular system; $\rho_{1}-\rho_{4}-$ weighting factors of the components of the integrated assessment; $\mathrm{q}_{1}-\mathrm{q}_{4}-$ indicators (primary assessments) of the components of the integrated assessment 
Using the logical sequence of the structural of predicted the model of integrated assessment of physical fitness, in the presence of numerical values of the levels of indicators of the components of integrated assessment, it is possible to determine the level of overall integrated assessment of physical fitness of youth for military service.

$$
R=\sum_{j=1}^{4} r_{j}=\sum_{j=1}^{4} \mathrm{q}_{j} p_{j}
$$

where: R - integrated assessment of young people's physical readiness for military service; $r_{j}$ - levels of indicators of integrated assessment; $q_{j}$ - indicators (primary assessments) of the components of the integrated assessment; $\rho_{j}$ - weighting factors of the components of the integrated assessment.

Assessment (testing) of the level of all components of the integrated assessment of physical fitness should take place in stages during the current and final annual (semester) controls on the subject "Physical Culture" (Peleshenko, 2010).

In order to determine the quantitative measure of the degree of importance and priority of each of the indicators integrated estimation, for the objective determination of the quality of the educational process in the direction of operation of the educational subject "physical culture" and to implement long-term prognosis effectiveness of its results, we analyzed the characteristics of complex components of the studied evaluations received through the feedback channel and with the help of expert evaluation.

To implement a remote forecast of the effectiveness of the forecast model, we conducted a comprehensive analysis

Table 1. Coefficients of weight of components of integrated assessment of physical readiness of youth for military service in security and defense forces

\begin{tabular}{lcc}
\hline \multicolumn{1}{c}{$\begin{array}{c}\text { Components of integrated } \\
\text { assessment }\end{array}$} & \multicolumn{2}{c}{ The value of the components } \\
\cline { 2 - 3 } & symbol & $\begin{array}{c}\text { weighting } \\
\text { factor }\end{array}$ \\
\hline $\begin{array}{l}\text { Level of formation and development } \\
\text { of general physical qualities }\left(\mathrm{r}_{1}\right)\end{array}$ & $\rho_{1}$ & 0.411 \\
$\begin{array}{l}\text { Level of formation and development } \\
\text { of special physical qualities }\left(\mathrm{r}_{2}\right)\end{array}$ & $\rho_{2}$ & 0.235 \\
$\begin{array}{l}\text { Level of acquisition of military- } \\
\text { applied motor skills }\left(\mathrm{r}_{3}\right)\end{array}$ & $\rho_{3}$ & 0.216 \\
\begin{tabular}{l} 
Cardiovascular status $\left(\mathrm{r}_{4}\right)$ \\
\hline
\end{tabular} & $\rho_{4}$ & 0.138 \\
\hline
\end{tabular}

of certain characteristics with the determination of a quantitative measure of the coefficient of weight (and priority) of each of the indicators of integrated assessment (Tabl. 1).

According to the results of the expert assessment, we obtained the average indicators of weights for all its components of the integrated assessment of the physical readiness of young people for service in the army. The level of formation and development of general physical qualities $\left(r_{1}\right)$ had the highest weighting factor $\left(\rho_{1}=0.411\right)$. The state of the cardiovascular system $\left(r_{4}\right)$ by the coefficient of severity was the lowest $\left(\rho_{4}=0.138\right)$, although it is generally accepted that the functionality limits the manifestation of physical qualities.

Each of the above components is only conditionally separated in a holistic integrated assessment of the physical readiness of young people for military service, integrates with other indicators and components and is a partial manifestation of this assessment.

Diagnosis of components in our study was carried out by quantifying the degree of their importance, completeness, stability of manifestation, the presence of possible deviations or shortcomings in relation to the purpose and objectives of physical fitness of young people for service in the army. If such deviations occur, it is necessary to analyze what they are, what caused them, what should be done to eliminate them and prevent them in the future. Without evaluative control, and correction of erroneous actions, learning will be "blind", it is impossible to manage, that is, it ceases to be at all "managed", its results will become unpredictable.

The generalized definition of an integrated assessment of the effectiveness of the process of physical education is the physical readiness of young people, which manifests itself in the form of the ability to serve in the army.

All indicators $r_{1}-r_{4}$ are evaluated in points from 1 to 12 . 1-3 points (low level), 4-6 points (medium), 7-9 points (sufficient), 10-12 (high). Using the coefficients $\mathrm{p}_{1}-\mathrm{p}_{4}$ determine the limits of the levels of the components $\mathrm{q}_{1}-\mathrm{q}_{4}$ of the integrated assessment.

Thus, we can determine the level of formation of individual components of the integrated physical fitness of young people for military service (Table 2), as well as adjust the content of physical education depending on such components that lag behind the appropriate norm.

The basis of physical readiness of young people for service in the army was the understanding that each of the components included in the content of the educational process in the field of "physical culture (education)" is an indicator

Table 2. Assessment of the level of formation of the components of integrated physical fitness (points)

\begin{tabular}{ccccccc}
\hline \multirow{2}{*}{$\sum_{n} r$} & $\mathbf{P}_{\mathbf{j}}$ & \multicolumn{5}{c}{ Score q (points) } \\
\cline { 3 - 7 } & & $\mathbf{q}_{\mathbf{j}}$ & $\mathbf{1 2 - 1 0} \mathbf{p}$ & $\mathbf{9 - 7} \mathbf{p}$ & $\mathbf{6 - 4} \mathbf{p}$ & $\mathbf{3} \mathbf{p}$ and less \\
\hline $\mathrm{r}_{1}$ & $\rho_{1}=0.411$ & $\mathrm{q}_{1}$ & $4.93-4.11$ & $3.70-2.88$ & $2.47-1.64$ & 1.23 \\
$\mathrm{r}_{2}$ & $\rho_{2}=0.235$ & $\mathrm{q}_{2}$ & $2.82-2.35$ & $2.16-1.64$ & $1.41-0.94$ & 0.71 \\
$\mathrm{r}_{3}$ & $\rho_{3}=0.216$ & $\mathrm{q}_{3}$ & $2.59-2.16$ & $1.94-1.51$ & $1.30-0.87$ & 0.65 \\
$\mathrm{r}_{4}$ & $\rho_{4}=0.138$ & $\mathrm{q}_{4}$ & $1.66-1.38$ & $1.24-0.97$ & $0.83-0.55$ & 0.41 \\
$\mathrm{R} \mathrm{iнт}$ & $\sum_{j}^{4} r j$ & & $12-10$ & $9-7$ & $6-4$ & 3
\end{tabular}

Notes: $r_{1}$ - the level of formation of general physical qualities; $r_{2}-$ the level of formation of special physical qualities; $r_{3}-$ level of applied physical fitness; $r_{4}$ - state of operation cardiovascular system; $\rho_{1}-\rho_{4}$ - weighting coefficient of the components of the integrated assessment; $\mathrm{q}_{1}-\mathrm{q}_{4}$ - indicators of the components of the integrated assessment. 
of the effectiveness of pedagogical influence and is used to achieve a useful end result.

\section{Discussion}

To determine the systemic approaches and ways to implement the basic principles of improving the military and physical training of the youth of Ukraine, a comparative analysis of the concepts, content and features of the organization of the physical training of the armed forces of leading NATO member states and Ukraine.

The results of the analysis of organizational and methodological principles of physical training systems of the armed forces of the leading member states of NATO and Ukraine allow us to state (Glazunov, 1978; Olkhovy, 2012; Romanchuk, 2013; Krutsevych, Panhelova, Pidletyichuk, 2021) that the main conceptual directions of modernization of approaches to organization and content in the armed forces of the North Atlantic Block and Ukraine have systems of physical training:

- high initial level of physical fitness of young people serving in the armed forces;

- intensification of the process of physical training;

- increasing the level of general physical fitness of servicemen;

- priority development of military-applied orientation of the process of physical training;

- sports orientation of the process of physical training;

- ensuring the functional readiness of the body of each serviceman to perform official and combat tasks.

According to the results of the analysis of scientific, periodical and documentary sources of reform in the physical training systems of the armed forces of the leading NATO member states, changes in the concepts of physical training were associated (Glazunov, 1978; Knapik, 1989; Bazhukov, 1996; Romanchuk, 2013).

Thus, the long-standing concept of physical fitness "physical fitness" has been replaced by "physical fitness". According to the definitions, "physical fitness" characterizes the adaptation of a serviceman to the content and conditions of activity, and "physical readiness" - the ability of individual servicemen and units to perform long and difficult professional activities in conditions of physical and mental stress (Olkhovy, 2013; Krasota, Olkhovyi, Romanchuk, 2014; Olkhovyi, Finohenov, 2015; Romanchuk, Anokhin, Oderov, Klymovyh, Pidleteichuk, Dobrovolskii, Tychyna, 2020).

There are two levels of physical fitness - full and operational. Full physical readiness is considered to be the ability of troops to mobilize their physical and mental resources to perform tasks, and operational - the readiness of troops to immediately perform their tasks in any environmental conditions (Brovkin, 1990; Magliovany, Petruk, Lesko, Kozhukh, 2015).

Requirements for the physical training systems of the armed forces of the leading NATO member states are conditioned by the main provisions of the general block strategic doctrine and the Concept of combat use of armed forces and methods of combat operations (strategy of "direct confrontation" and the concept of "continuous combat") (Olhovyi, 2013;) and air-ground operations (Ignatiev, 2007).

The physical training systems of the leading NATO member states operate on the basis of three different con- cepts - "preparadness", "readiness" and "mobilization", which are provided by three different areas of physical training - traditional, military and sports (Valeryn, 1992; Romanchuk, 2012).

Today, the armed forces of the world's leading nations do not have a single concept of physical training. This is due to the different socio-economic conditions of each country, which determine the features of the recruitment and combat training of personnel of the armed forces (Borodin, 2009; Bosenko, Sudets, 2017).

In modeling an integrated assessment of physical fitness of young people for military service, complex processes are considered in "pure form" by constructing abstract schemes of real processes necessary for deeper penetration into the patterns of their course and prediction of possible directions of development, which included the following components: physical qualities; the level of formation and development of special physical qualities; the level of formation of militaryapplied motor skills and abilities; the state of the cardiovascular system.

The level of formation and development of general physical qualities, as a fundamental component of integrated assessment, is assessed by the practical implementation of exercises: pull-ups on the crossbar, running at 100 (60) $\mathrm{m}$, running at $3000 \mathrm{~m}$ (Physical Training Manual, 2014).

The level of formation and development of special physical qualities and the acquisition of military-applied motor skills as integral components of integrated assessment, is assessed by the practical implementation of special exercises: "comprehensive dexterity exercise", overcoming obstacles, performing hand-to-hand combat techniques, swimming in clothing weighing $2 \mathrm{~kg}$, diving in length, movement of 5000 $\mathrm{m}$ with a weight of $3 \mathrm{~kg}$, "angle" in the focus on the bars, a comprehensive coordination exercise, etc. (Bosenko, Sudets, 2017).

The state of the cardiovascular system is assessed by the Robinson index, which characterizes the energy potential - together with the adaptive potential is the most sensitive marker of the state of the cardiovascular system and the adaptive mechanisms of the human body.

\section{Conclusion}

In the literature, recommendations for the assessment of general physical fitness and special physical fitness provide only a list of motor tests with the limits of their manifestation (Physical Training Manual, 2014) and there is no integrated assessment of physical fitness of conscripts for military service.

In our research, for the first time, the contribution of each component (general physical fitness, special physical fitness, military-applied physical fitness and the state of the cardiovascular system) of the integrated assessment of physical fitness of young people was determined. This opens up the possibility of filling this model with concrete results in motor tests to determine the sufficiency or insufficiency of certain aspects of training and the focus of physical training of an individual young man to achieve appropriate standards.

Structural projected model of integrated assessment of physical readiness of youth for service in the army allows to determine the limits of levels of components and to estimate the level of their formation in points from 1 to $12.1-3$ points 
(low level), 4-6 points (average), 7-9 points (sufficient), 10-12 (high), relative to the appropriate rate and obtain an objective assessment of the effectiveness of the process of physical training of pre-conscription youth.

\section{Conflict of Interest}

The authors declare that there is no conflict of interest.

\section{References}

Krutsevich, T., \& Trachuk, S. (2017). Normatyvni osnovy suchasnoyi systemy fizychnoho vyxovannya riznyx hrup naselennya Ukrayiny. Sportyvnyj visnyk Prydniprovya, (1), 184-188.

Krutsevych, T., Sainchuk, M., \& Pidleteichuk, R. (2018). Naslidky politykyt devalvatsii fizychnoi pidhotovky u fizychnomu vykhovanni osvitnikh zakladiv Ukrainy dlia hromadian i derzhavy. Naukovyi chasopys NPU imeni Drahomanova, (2), 51-55.

Military Committee (2009). MC policy for NATO concept development and experimentation (MC 0583). Brussels, Belgium: North Atlantic Treaty Organization.

Borodin, Yu. A. (2009). Fizychna pidhotovka kursantiv u vyshchykh viiskovykh navchalnykh zakladakh inzhenernooperatorskoho profiliu [monohrafiia]. Kyiv: NPU imeni M. P. Drahomanova.

Romanchuk, S. V. (2012). Fizychna pidhotovka kursantiv viiskovykh navchalnykh zakladiv Sukhoputnykh viisk Zbroinykh Syl Ukrainy: [monohrafiia]. Lviv: ASV, 367 s.

Bosenko, A.I., \& Sudets, S.V. (2017). Fizychna pidhotovlenist i systema yii otsinky u dopryzovnoi molodi Ukrainy. Naukovyi chasopys NPU imeni M.P. Drahomanova, 3(84), 87-91.

Aandstad, A., Sandberg, F., Hageberg, R., \& Kolle, E. (2020). Change in Anthropometrics and Physical Fitness in Norwegian Cadets During 3 Years of Military Academy Education. Military Medicine, 185(7-8), e1112-e1119. https://doi.org/10.1093/milmed/usz470

Romanchuk, S. V. (2013). Teoretyko-metodychni zasady fizychnoi pidhotovky kursantiv viiskovykh sukhoputnykh navchalnykh zakladiv Zbroinykh syl Ukrainy (dysertatsiia). Lviv: Lvivskyi derzhavnyi universytet fizychnoi kultury imeni Ivana Boberskoho.

Olkhovoi, O. M. (2012). Model gotovnosti budushchikh ofitcerov k upravleniiu fizicheskoi podgotovkoi. Fizicheskoe vospitanie studentov. Nauch. zhurnal. Kh., KhOONOKU, (3), 94-97.

Romanchuk, S., Anokhin, S., Tychyna, I., Dobrovolskii, V., Pidleteichuk, R., Homanyuk, S., Kirpenko, V., Oderov, A., \& Klymovych, V. (2020) The impact of mass sports work in educational institution on the formation of cadets' value attitude towards physical education. Sport Mont, 18(1), 81-86. https://doi.org/10.26773/smj.200214

Priymak, S. (2003). Modelyuvannya parametriv fizychnoyi pidhotovlenosti pidlitkiv u protsesi fizychnoho vykhovannya [dysertatsiia]. Lviv : LDUFK.

Loshytska, T.I. (2007). Modelno-tsilovi kharakterystyky fizychnoi pidhotovlenosti yunakiv pryzovnoho viku v systemi fizychnoho vykhovannia [dysertatsiia]. Kyiv:
Natsionalnyi universytet fizychnoho vykhovannia i sportu Ukrainy.

Priymak, S., Krutsevich, T., Pangelova, N., Trachuk, S., Kravchenko, T., Stepanenko, V., \& Ruban, V. (2020). Modeling of functional support of sports activities of biathletes of different qualifications. Journal of Human Sport and Exercise, 16(1). https://doi.org/10.14198/jhse.2021.161.12

Olkhovyi, O. M. (2012). Teoretyko-metodychni osnovy profesiino-spriamovanoi FP kursantiv VVNZ ZS Ukrainy: monohrafiia. Kh.: KhUPS.

Krutsevich, T. (2017). Teoriya ta metodyka fizychnoho vyxovannya: pidruchnyk dlya studentiv vyshhyx navchalnyx zakladiv ta sportyvnyx vuziv: u 2 knyhax. Kiev: Olympic literature.

Krutsevich, T., Pangelova, N., \& Trachuk, S. (2019). Modeltarget characteristics of physical fitness in the system of programming sports and recreational activities with adolescents. Journal of Physical Education and Sport, 19(Supplement issue 1), 242-248. https://doi.org/10.7752/jpes.2019.s1036

Peleshenko, I. (2010). Otsinyuvannya rukhovykh zdibnostey uchniv za dopomohoyu kompleksnoho testuvannya v zahalnoosvitnikh navchalnykh zakladakh. Slobozhanskyy naukovo-sportyvnyy visnyk, (2), 35-38.

Glazunov, N. K.(1978). Strategicheskie kontceptcii i razvitie vooruzhennykh sil Severoatlanticheskogo soiuza. Voen. ist. zhurn., (11), 80-86.

Krutsevych, T.Yu., Panhelova, N.Ye, \& Pidletyichuk, R.M. (2021). Kontseptualni pidkhody do orhanizatsii systemy fizychnoi pidhotovky viiskovosluzhbovtsiv providnykh krain NATO. Teoriia i metodyka fizychnoho vykhovannia i sportu, 21(2).

Knapik, J.(1989). The Army Physical Fitness Test (APFT): a review of the literature. Mil Med. Jun;154(6):326-9. PMID: 2498771. https://doi.org/10.1093/milmed/154.6.326

Krasota, V., Olkhovyi, O., \& Romanchuk, S. (2014). Vzaiemozalezhnist profesiinoi ta fizychnoi hotovnosti maibutnikh ofitseriv. Teoriia i metodyka fizychnoho vykhovannia i sportu, 1, 42-46.

Olkhovyi, O.M., \& Finohenov, Yu.S. (2015). Kontseptsiia fizychnoi pidhotovky Zbroinykh syl Ukrainy. $X V$ Mizhnarodna naukovo-praktychna konferentsiia "Fizychna kultura, sport ta zdorovia". Kh., S.173-174.

Brovkin, V. (1990). Komplektovanie vooruzhennykh sil Velikobritanii. Zarubezhnoe voennoe obozrenie, (13), 13-15.

Mahlovanyi, A., Petruk, A., Lesko, O., \& Kozhukh, N. (2015). Fizychna pidhotovka v systemi formuvannia viiskovykh fakhivtsiv providnykh inozemnykh armii. Sportyvna nauka Ukrainy, (69), 16-20.

Olkhovyi, O. M. (2013). Kontseptsiia profesiino spriamovanoi systemy fizychnoi pidhotovky kursantiv. Visnyk Chernihivskoho natsionalnoho pedahohichnoho universytetu im. T.H Shevchenka, (112), 208-211.

Ignatev, O. (2007). Osnovnye napravleniia razvitiia VVS evropeiskikh stran NATO na period do 2015-2020 godov. Zarubezhnoe voennoe obozrenie, (5), 36. 
Saaty, T. L., \& Kearns, K. P. (1985). Analytical Planning The

Organization of Systems. Pergamon Press.

Saati, T.L. (2010). Priniatie reshenii pri zavisimostiakh $i$ obratnykh sviaziakh. Analiticheskie seti. 3-e izd. M.: URSS.
Nastanova z fizychnoi pidhotovky u Zbroinykh sylakh Ukrainy. (NFP - 2014). Kyiv: Ministerstvo oborony Ukrainy, 2014. $158 \mathrm{~s}$.

Valeryn, V. (1992). Sily bystrogo razvertyvaniia v planakh NATO. Zarubezhnoe voennoe obozrenie, (5), 29-30.

\title{
МОДЕЛЮВАННЯ НАЛЕЖНИХ НОРМ ФІЗИЧНОЇ ГОТОВНОСТІ ДОПРИЗОВНОї МОЛОДІ ДО СЛУЖБИ В АРМІї
}

\author{
Тетяна Круцевич ${ }^{1 \mathrm{ABCD}}$, Наталія Пангелова ${ }^{2 \mathrm{ABCD}}$, Сергій Трачук ${ }^{1 \mathrm{ABCD}}$, \\ Віктор Куйбіда $^{2 A B C D}$, Роман Підлетийчук ${ }^{1 A B C D}$, Борис Пангелов ${ }^{2 A B C D}$
}

\author{
${ }^{1}$ Національний університет фізичного виховання та спорту України \\ ${ }^{2}$ Університет Григорія Сковороди в Переяславі
}

Авторський вклад: А - дизайн дослідження; В - збір даних; С - статаналіз; D - підготовка рукопису; Е - збір коштів

Реферат. Стаття: 6 с., 1 рис., 2 табл., 25 джерел.

Мета дослідження - обгрунтувати та змоделювати належні норми фізичної підготовленості молоді до служби в армії.

Матеріали і методи. До складу експертної групи увійшов 21 спеціаліст (сферою діяльності яких є фізичне виховання, спецпідготовка, фізична підготовка в силах безпеки та оборони). Для розв'язання поставленої в роботі проблеми використано такі методи дослідження: теоретичний аналіз, порівняння, систематизація та узагальнення матеріалів наукової, історичної, методичної літератури та методичних документів; експертна оцінка (Delphi та аналіз iєpapxiй Saati); методи математичної статистики.

Результати. Визначено, що прості статистичні методи в поєднанні з експертною інформацією при виборі перспективних рішень часто дають кращі результати, ніж точні розрахунки з орієнтацією на середні значення. Комплексний підхід з використанням експертної оцінки (Delphi), методу сучасної теорії ієрархічних систем Сааті дозволив визначити структуру прогнозованої моделі фізичної підготовленості молоді до військової служби. Структурними, взаємопов'язаними компонентами прогнозованої моделі 3 відповідними ваговими коефіцієнтами є рівень сформованості та розвитку загальних і спеціальних фізичних якостей $\left(\rho_{1}=0,411\right)$, рівень сформованості та розвитку спеціальних фізичних якостей $\left(\rho_{2}=0,235\right)$, рівень набуття військовоприкладної моторики $\left(\rho_{3}=0,216\right)$, стан серцево-судинної системи $\left(\rho_{4}=0,138\right)$.

Висновки. Представлена структурна модель комплексної оцінки фізичної підготовленості молоді до служби в армії дозволяє визначити складові компоненти і оцінити рівень їх сформованості в балах від 1 до 12, а також відкоригувати зміст засобів фізичної підготовки залежно від тих компонентів, які відстають від належної норми.

Ключові слова: допризовна молодь, прогнозовані моделі, належні норми, фізична підготовленість.

\section{Information about the authors:}

Krutsevich T.: tmfv@ukr.net; https://orcid.org/0000-0002-4901-6148; Department of Theory and Methods of Physical Education, National University of Ukraine on Physical Education and Sport, Fizkultury St, 1, Kyiv, 03150, Ukraine.

Panhelova N.: kafedra.tmfvis@ukr.net; https://orcid.org/0000-0002-4846-3907; Department of Theory and Methods of Physical Education and Sports, Hryhorii Skovoroda University in Pereiaslav, Sukhomlynskoho St, 30, Pereiaslav, 08401, Kyiv region, Ukraine.

Trachuk S.: trachuk_sergey@i.ua; https://orcid.org/0000-0002-5580-0510; Department of Theory and Methods of Physical Education, National University of Ukraine on Physical Education and Sport, Fizkultury St, 1, Kyiv, 03150, Ukraine.

Kuibida V.: Viktor_kuybida@ukr.net; https://orcid.org/0000-0001-5865-1306; Department of Biology with teaching methods, Dean of the Faculty of Physical Education Hryhorii Skovoroda University in Pereiaslav, Sukhomlynskoho St, 30, Pereiaslav, 08401, Kyiv region, Ukraine.

Pidleteychuk R.: https://orcid.org/0000-0002-9176-8570; Department of Theory and Methods of Physical Education, National University of Ukraine on Physical Education and Sport, Fizkultury St, 1, Kyiv, 03150, Ukraine.

Pangelov B.: sportkaf@ukr.net; https://orcid.org/0000-0003-3590-9428; Department of Sports, Games and Tourism, Hryhorii Skovoroda University in Pereiaslav, Sukhomlynskoho St, 30, Pereiaslav, 08401, Kyiv region, Ukraine.

Cite this article as: Krutsevich, T., Panhelova, N., Trachuk, S., Kuibida, V., Pidleteychuk, R., \& Panhelov, B. (2021). Modeling of Appropriate Norms of Physical Readiness of Pre-Conscription Youth for Service in the Army. Teoriâ ta Metodika Fizičnogo Vihovannâ, 21(4), 317-322. https://doi.org/10.17309/tmfv.2021.4.05

Received: 31.08.2021. Accepted: 16.10.2021. Published: 25.12.2021

This work is licensed under a Creative Commons Attribution 4.0 International License (http://creativecommons.org/licenses/by/4.0). 